\title{
Review of Dalit Literature and Criticism by Raj Kumar
}

\author{
Publisher: Orient BlackSwan \\ Year of Publication: 2019 \\ ISBN:978-93-5287-532-0 \\ Reviewed by \\ Shahida
}

Assistant Professor, Department of Humanities and Social Sciences, NIT Kurukshetra. Email: shahida2709@gmail.com

The term 'Dalit' refers to a particular group or community in India which have been ostracized, exploited and humiliated due caste structure and social order ardently followed in India. The etymology of the word 'Dalit' can be traced to the root word dal in Sanskrit and dalan in Hindi meaning 'broken down' or 'broken to pieces.' It is believed that Jotibarao Phule (1826-90) first used the term to describe condition of outcastes and untouchables in India. Later, the term was popularized by B.R. Ambedkar as he used it profusely in his speeches and writings in Marathi. The term gained new meaning in 1970s, a period of literary and cultural boom that witnessed the birth of Dalit literature and in the present, the term refers to belated recognition of the Dalit's militant claims upon a history of humiliation and suffering (Rao, 11).

Since its origin Dalit Literature has emerged as a form of social resistance literature principally aimed at community identity formation and bringing about political and economic changes among the Dalit population. Arjun Dangle, the Marathi Dalit writer, editor and activist suggests, "Dalit literature is marked by revolt and negativism, since it is closely associated with the hopes for freedom by a group of people, who as untouchables, are victims of social, economic and cultural inequality" (Trans. Mukhherjee; 1). Dangle traces the origin of Dalit literature to Ambedkar. It was his revolutionary ideas that encouraged Dalits to speak for themselves and therefore Dalit literature is an expression of this self- awareness; an assertion for a dignified life..

As a literary movement it continues to grow as new authors continue to add their individual voices to the collective outrage of resistance against caste based discrimination and humiliation suffered for ages. In the present writers and critics are working to carve out a niche for Dalit voice in both Indian and International literary contexts. A new generation of writers are transforming Dalit literature from merely a narrative of humiliation and exploitation to include issues such as feminism, literary self-consciousness, individual introspection, while increasingly wrestling with the question of how mainstream this literature may become without losing its authentic Dalit identity (Brueck, 153).

Raj Kumar's Dalit Literature and Criticism is an important text discussing an increasingly popular field of study-Dalit Studies. It is a concise text which covers almost all major aspects of Dalit literature and criticism. The greatest strength of this book is the systematic organization of ideas and simplicity of language. Divided into six chapters followed by a conclusion, glossary of literary terms and suggested reading, the book is an attempt to introduce Dalit literature and various critical practices to research scholars and general readers. Apart from literary criticism, the

(c) AesthetixMS 2020. This Open Access article is published under a Creative Commons Attribution Non-Commercial 4.0 International License (http://creativecommons.org/licenses/by-nc/4.o/), which permits non-commercial re-use, distribution, and reproduction in any medium, provided the original work is properly cited. For citation use the DOI. For commercial re-use, please contact editor@rupkatha.com. 
book also introduces several cultural concepts and key texts related to Dalit lives. Not only this, the book examines a work of fiction, Akhila Naik's Bheda, to demonstrate Dalit criticism in practice which is noteworthy.

In the first chapter, entitled as "Introducing the Concept of 'Dalit" Raj Kumar traces the history of origin of the term 'Dalit' and goes on to re-define the term and its context. He says that the term 'Dalit' is an existential condition of a group of people who were earlier known as 'untouchables.' Raj Kumar's discussion on the multiple definitions offered by critics and scholars of the term 'Dalit' proves to be very useful. He concludes the chapter by introducing the areas to be covered in subsequent chapters of the book. These areas included: causes of Dalit exploitation, emergence of Dalit literature, understanding of Dalit aesthetics, Dalit criticism in practice and pedagogical approaches to Dalit literature.

The second chapter explores the caste question leading to the emergence of 'Dalit' as a category. Raj Kumar goes on to discuss two opposing views regarding the history of origin of caste system in India which is quite informative. Beginning with the Western view he points out that the advent of caste system in India perhaps started with the Aryan invasion and consequent social oppression and enslavement of the native population. The other view put forth is the Brahminical view. This view is a mythological-religious theory which sees caste as a result of divine sanctions, with its origin mainly in the Purusha Sukta, a part of Rig Veda. However, both the theories rely on the internal evidence found in the Vedas and the post-Vedic literature. This chapter effortlessly seeks to answer questions like: What were the reasons for Dalits to be oppressed in the Indian caste society? Who exploited them? Who protested against the evils of caste system in India? What were the earliest reform movements that aimed at abolishing caste distinctions? Who were the reformers who raised their voice against untouchability and caste discrimination? What is the status of Dalits in Post-independence India? Raj Kumar has taken care of including almost all relevant details to answer the aforementioned questions which actually forms the basis of Dalit literature and criticism. He has successfully performed the task of introducing the basics of Dalit literature to readers who want to explore the field of Dalit literature and criticism.

For centuries literature belonged to those who wielded power and position due to their privileged status in society. Dalit literature is an outcry of those who were left on the margins: the outcaste, the oppressed, landless, indigenous groups. In the third chapter, Raj Kumar goes on to trace the emergence of Dalit literature in India. He begins with categorically enumerating reasons why Dalit literature remained largely unnoticed until the nineteenth century. In the medieval age, with the rise of Bhakti movement there were many poets from outcastes like the tailor Namdev, weaver Kabir, cobbler Ravidas, cotton comber Dadu Dayal, potter Gora, barber Sena and many more who sang songs of protest against the hegemony of Brahmanic Hinduism. And it was chiefly in the form of oral songs. It was only with the advent of Britishers and English education that brought about many changes in the social structure. English education introduced ideas of 'Enlightenment' leading to incorporation of democratic and secular ideas of reformation. English Missionaries opened schools for the 'untouchables' that further helped them to articulate their protests, concerns and sense of self (Kumar, 47). Yet the outcastes do not appear in Indian literary scene until the latter half of the nineteenth century.

Raj Kumar criticizes the upper-caste Hindu writers of the twentieth century who in their novels have tried to portray the lives of 'untouchables' with the aim of bringing about social reform or by sentimental compassion (49). He argues that these novels belong to genre of 'emotional' literature rather than Dalit literature because these characters are presented from the perspective of upper caste writers. The characters lacked realistic portrayal as human beings full of vitality, 
hope, as well as despair (50). He goes on to discuss Unnava Lakshminarayana's Malapalli to substantiate his argument. In this chapter Raj Kumar meticulously records the major events during rise of the Dalit literary movement in India. For young research scholars who wish to pursue Dalit Studies, this chapter proves to provide an excellent background to study-the beginning of Dalit Literary Movement/Dalit Literature in India.

Fourth chapter deals with 'Understanding Dalit Aesthetics'. In this chapter Raj Kumar foregrounds the philosophy of Dalit literature and theory. He emphasizes on the Dalit Aesthetics. Dalit literature is literature of resistance and since the 'downtrodden' had hardly any place in the established canonical of literature of India, Dalit writers tend to call the existing canon as 'Hindu Literature' and seek to challenge its hegemony (67). The merit of this chapter is concise description of Dalit theory, language used in texts, important genres in Dalit literature, Dalit mythology and translation of Dalit texts.

In the fifth chapter Raj Kumar examines Akhila Naik's Bheda as a Dalit text. Through the lenses of Dalit theory and criticism the text is interpreted at multiple levels. Raj Kumar clearly mentions that since Dalit criticism is comparatively new there has been hardly any theorization done so far. He goes on to demonstrate how a Dalit text need to be understood by first examining its title, then its narrative strategies followed by the development of discourse and finally the themes dominant in the text. This comprehensive analysis and comparison of the text Bheda along with other literary works such as Joseph Macwan's Angliyat, Kalyan Rao's Untouchable Spring, Sivakami's The Grip of Change, throughout the chapter presents Dalit Theory and criticism as a topic of social and political concern. It very much signifies that Dalit literature needs to be taken seriously and not relegated to the margins and ignore these texts as they are not being written according to the standards of Western literature or by higher castes. Also, the chapter can be appreciated for presenting a brief history of birth of Dalit writings in Odisha. Raj Kumar has taken care of acquainting the readers with the history and writings of many prominent Odia Dalit writers as well.

The sixth chapter foregrounds the 'Pedagogical Approaches to Dalit Literature.' Raj Kumar focusses on discussing in detail the growth and development of general consciousness about Dalit contexts and how students and teachers from several universities both in India and abroad are taking up research on Dalit related subjects. Consequently, like Cultural Studies and Gender Studies, Dalit Studies is now established as a full-fledged autonomous discipline in colleges and universities.

Raj Kumar concludes the book with insightful analysis of Dalit Literature and Aesthetics. Though Dalit Studies is established as a distinct field of study yet the field of Dalit criticism is least explored. This book successfully bridges this gap as it has addressed all major issues concerning Dalit literature. For a research scholar who is interested in Dalit Studies this book is definitely very helpful in introducing the key concepts of Dalit literature and criticism-including its history, themes, aesthetics and culture.

Dalit Literature and Criticism, includes a 'Glossary of Select Literary Terms' and a list of books as 'Suggested Reading' in the end of the book. Dalit literature is literature of resistance; an outcry against all forms of humiliations suffered due to caste discrimination and social hierarchical structures. Most of the Dalit literature is written by Dalit writers/activists who prefer to document their experiences in their language often mother tongue which is the beauty of this literature. Thus, rightly argued by Sharankumar Limbale that: 
Dalit writers [have] rejected traditional aesthetics of both India and the West and constructed separate aesthetics of their own... the distinctive features of Dalit literature thus: Dalit literature upholds equality, freedom and justice; it emphasizes the centrality of the human being and society and therefore it is revolutionary. Suffering and revolutionary awakening is the basis of Dalit literature (Barak et al.;3).

\section{References}

Barak, Judith Misrahi et al. (2020). "Introduction.” Dalit Text: Aesthetics and Politics Re-imagined. Ed. Judith Misrahi Barak et al. New York: Routledge. (pp. 166-18o)

Brueck, Laura R (2008). "Mainstreaming Marginalized Voices: The Dalt Lekhak Sangh and the Negotiations over Hindi Dalit Literature." Claiming Power from Below: Dalits and the Subaltern Question in India. Ed. Manu Bhagavan and Anne Feldhaus. New Delhi: Oxford University Press. (pp. 151-165).

Kumar, Raj (2019). Dalit Literature and Criticism. Hyderabad: Orient BlackSwan.

Limbale, Sharankumar (2004). Towards an Aesthetic of Dalit Literature: History, Controversies and Consideration. Trans. Alok Mukherjee. Hyderabad: Orient BlackSwan.

Maya Pandit (2020). "Translating Dalit Literature: Re-drawing the Map of Cultural Politics." Dalit Text: Aesthetics and Politics Re-imagined. Ed. Judith Misrahi Barak, K. Satyanarayana and Nicole Thiara. New York: Routledge. (pp. 166-18o)

Pai, Sudha (2013) Dalit Assertion. New Delhi: Oxford University Press.

Rao, Anupama (2008). "Who is the Dalit? The Emergence of a New Political Subject." Claiming Power from Below: Dalits and the Subaltern Question in India. Ed. Manu Bhagavan and Anne Feldhaus. New Delhi: Oxford University Press. (pp. 11-27).

Zelliot, Eleanor (2004). Ambedkar's World: The Making of Babasaheb and the Dalit Movement. Navayana: Delhi. 